\title{
Extensive tendon and tuberous xanthomas in a patient with familial hypercholesterolaemia
}

\author{
Ayan Roy (1), Sadishkumar Kamalanathan, Dukhabandhu Naik, Jaya Prakash Sahoo
}

Endocrinology, Jawaharlal Institute of Postgraduate Medical Education and Research, Puducherry, India

\section{Correspondence to} Dr Jaya Prakash Sahoo; jppgi@yahoo.com

Accepted 13 August 2020

Check for updates

(C) BMJ Publishing Group Limited 2020. No commercial re-use. See rights and permissions. Published by BMJ.

\footnotetext{
To cite: Roy $A$,

Kamalanathan S, Naik D,

et al. BMJ Case Rep

2020;13:e236759.

doi:10.1136/bcr-2020-

236759
}

\section{DESCRIPTION}

A 37-year-old man came to endocrinology out patient department with erectile dysfunction for 2 years. His libido was normal and he had no history of decrease in shaving frequency or loss of axillary and pubic hair. He did not have diabetes or hypertension. However, he had an episode of acute severe chest pain in May 2018, when he was diagnosed with an abdominal aortic aneurysm. He underwent aortic stenting in June 2018. Subsequently, he developed a leak in the graft, and glue repair was performed in August 2018. During the evaluation, he was found to have several swellings in the bilateral knee region and one of the swellings was excised during aneurysm repair. The histopathology report showed nodules with numerous cholesterol deposits in the centre surrounded by mild lymphohistiocytic infiltrates and separated by fibrous bands; suggestive of tuberous xanthoma. He was put on aspirin $150 \mathrm{mg}$, atorvastatin $40 \mathrm{mg}$ and clopidogrel $75 \mathrm{mg}$ as a secondary prophylaxis and was referred to the endocrinology department for metabolic workup.

On further inquiry, he revealed that he is having multiple swellings around the elbow, hip, knee, and ankle areas since childhood. He also confirmed that his elder sister has similar swellings. Nevertheless, his father died at the age of 30 years but the exact cause of death is not known. But, he denied any other family history of premature atherosclerotic cardiovascular disease or premature death related to cardiac disease. His physical examination revealed a body mass index of $21.1 \mathrm{~kg} / \mathrm{m}^{2}$ and normal blood pressure. He had bilateral incomplete corneal arcus involving mainly the superior and inferior limbus of the cornea (figure 1A). He had extensive multiple large, globular, non-tender, soft to firm swellings around the knee, ankle, elbow and small joints of the feet (figure 1B-D). He had thickening and widening of the Achilles tendons in both the legs (figure 1D,E).

Standing lateral X-ray of the right foot showed a width of the Achilles tendon as $3.12 \mathrm{~cm}(<9 \mathrm{~mm}$ is normal ${ }^{1}$ ) (figure 1F). On the other hand, he had normal secondary sexual characters with a bilateral testicular volume of $20 \mathrm{ml}$.

His lipid profile was as follows: total cholesterol: $469 \mathrm{mg} / \mathrm{dL}$; low-density lipoprotein (LDL): $353 \mathrm{mg} / \mathrm{dL}$; triglyceride (TG): $103 \mathrm{mg} / \mathrm{dL}$; very LDL (VLDL):24 mg/dL and high-density lipoprotein (HDL): $44 \mathrm{mg} / \mathrm{dL}$. His thyroid function was normal and morning ( $8 \mathrm{AM}$ ) serum testosterone was $600 \mathrm{ng} / \mathrm{dL}$, ruling out underlying hypogonadism. We screened her 63-year-old mother who was asymptomatic. She had no xanthoma on physical examination. But, her lipid profile was suggestive of severe hypercholesterolaemia: total cholesterol: $513 \mathrm{mg} / \mathrm{dL} ;$ LDL: $335 \mathrm{mg} / \mathrm{dL}$; TG: $190 \mathrm{mg} / \mathrm{dL}$; VLDL: $44 \mathrm{mg} / \mathrm{dL}$ and HDL: $60 \mathrm{mg} / \mathrm{dL}$. The index patient was diagnosed with familial hypercholesterolaemia (FH) (possibly homozygous) and was started on atorvastatin $80 \mathrm{mg}$ along with ezetimibe $20 \mathrm{mg}$ daily. His erectile dysfunction was attributed to possible vascular aetiology.

Tendon with or without tuberous xanthomas are usually considered as a pathognomonic clinical sign of homozygous FH. Nevertheless, many differentials should be considered before establishing the diagnosis.Tendon xanthomas can also be seen in patients with heterozygous $\mathrm{FH}(\mathrm{HeFH}) .{ }^{2}$ However, they are not evident at the time of $\mathrm{HeFH}$ diagnosis nowadays, because of widely prescribed lipidlowering therapy. Extensive xanthomas are rarely seen nowadays. Importantly, xanthomas are often missed and consequently, treatments are delayed. ${ }^{3}$ Other differentials for this patient are autosomal recessive hypercholesterolaemia, cerebrotendinous xanthomatosis and sitosterolaemia. However, the absence of neurological involvement excludes the possibility of cerebrotendinous xanthomatosis. Sitosterolaemia is an autosomal recessive disorder characterised by the accumulation of plant sterols and is often associated with haematological manifestations like haemolytic anaemia, stomatocytes and macrothrombocytopenia. The absence of such abnormalities and a dominant inheritance pattern makes the diagnosis of sitosterolaemia unlikely in this patient. Finally, a genetic analysis would have been helpful to characterise the defect exactly.

Heterozygous and homozygous FH have a prevalence of one in 250-500 and one in 1 million respectively worldwide. ${ }^{4}$ Tendon and tuberous xanthomas serve as an important clinical clue to

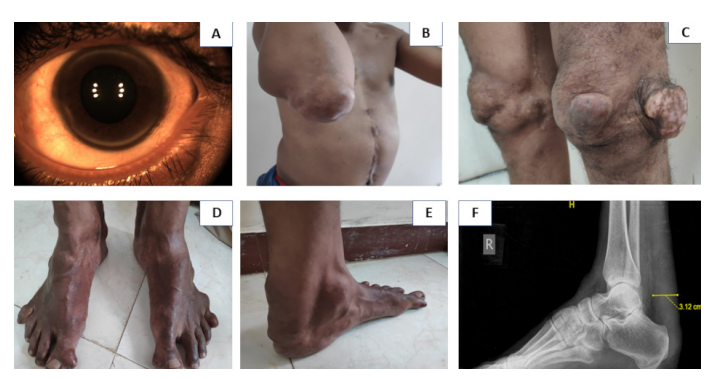

Figure 1 Clinical photograph of the patient showing corneal arcus (A), Xanthomas around Elbow (B), Knee(C) and Foot(D). There is also severe thickening of the Achiles tendon clinically $(\mathrm{E})$ and radiologically $(\mathrm{F})$. 


\section{Learning points}

- Tendon with or without tuberous xanthomas are a pathognomonic clinical sign of familial hypercholesterolaemia (FH), which is often missed.

- FH should be considered in a patient with premature cardiovascular disease without traditional risk factors.

- Early diagnosis of FH can facilitate the management of this common disorder and help prevent future cardiovascular events in family members.

- Autosomal recessive hypercholesterolaemia, cerebrotendinous xanthomatosis and sitosterolaemia are other differentials of tendon xanthomas presenting with elevated low-density lipoprotein cholesterol levels.

the diagnosis of FH aiding in early treatment. Nevertheless, the commonly prescribed statins are not very effective in homozygous FH. Currently, LDL apheresis along with innovative therapies such as PCSK9 inhibitors or Lomitapide are a part of the standard care.
Contributors AR acquired the clinical data and drafted the manuscript. SK, JPS and DN supervised the work and revised the manuscript with intellectual input.

Funding The authors have not declared a specific grant for this research from any funding agency in the public, commercial or not-for-profit sectors.

Competing interests None declared.

Patient consent for publication Obtained.

Provenance and peer review Not commissioned; externally peer reviewed.

\section{ORCID iD}

Ayan Roy http://orcid.org/0000-0003-4419-9376

\section{REFERENCES}

1 Harada-Shiba M, Arai H, Ishigaki Y, et al. Guidelines for diagnosis and treatment of familial hypercholesterolemia 2017. J Atheroscler Thromb 2018;25:751-70.

2 Aljenedil S, Ruel I, Watters K, et al. Severe xanthomatosis in heterozygous familial hypercholesterolemia. J Clin Lipidol 2018;12:872-7.

3 Nordestgaard BG, Chapman MJ, Humphries SE, et al. Familial hypercholesterolaemia is underdiagnosed and undertreated in the general population: guidance for clinicians to prevent coronary heart disease: consensus statement of the European atherosclerosis Society. Eur Heart J 2013;34:3478-90.

4 Cuchel M, Bruckert E, Ginsberg HN, et al. Homozygous familial hypercholesterolaemia: new insights and guidance for clinicians to improve detection and clinical management. A position paper from the consensus panel on familial hypercholesterolaemia of the European atherosclerosis Society. Eur Heart J 2014;35:2146-57.

Copyright 2020 BMJ Publishing Group. All rights reserved. For permission to reuse any of this content visit

https://www.bmj.com/company/products-services/rights-and-licensing/permissions/

BMJ Case Report Fellows may re-use this article for personal use and teaching without any further permission.

Become a Fellow of BMJ Case Reports today and you can:

- Submit as many cases as you like

- Enjoy fast sympathetic peer review and rapid publication of accepted articles

- Access all the published articles

Re-use any of the published material for personal use and teaching without further permission

\section{Customer Service}

If you have any further queries about your subscription, please contact our customer services team on +44 (0) 2071111105 or via email at support@bmj.com.

Visit casereports.bmj.com for more articles like this and to become a Fellow 